\title{
DON'T PUT ALL YOUR EGGS IN FOREIGN BASKETS
}

\section{SANTIAGO CAMARA ${ }^{1}$}

\begin{abstract}
I analyze the sluggish response of exports during and after financial crises using firm level data for two countries-episodes: Argentina 2001 and Peru 1998 crises. I find that both incumbent exporting firms do not expand and that there's no significant entry of new exporting firms. Furthermore, I present evidence that suggests that the export elasticity to the real exchange rate is asymmetric, smaller for depreciations than for appreciations. I build and estimate a DSGE model for a small open economy where exporting entrepreneurs are subject to financial frictions and balance sheet effects in order to try and explain these stylized facts. Although these frictions decrease the response of exports to movements in the exchange rate, I use computational exercises to show that they are not enough to explain the empirical results.
\end{abstract}

Keywords: Macroeconomics, International Trade, Sudden Stops

\section{NO PONGAS TODOS TUS HUEVOS EN CANASTAS EXTRANJERAS}

\section{RESUMEN}

Analizo la lenta expansión de las exportaciones durante y después de crisis financieras utilizando datos a nivel firma para dos países-episodios: Argentina 2001 y Perú 1998. Encuentro que firmas exportadoras incumbentes no expanden sus ventas y que no hay un sustancial aumento de firmas exportadoras. Aún más, presento evidencia que sugiere que la elasticidad de las exportaciones al tipo de cambio real es asimétrica, menor para depreciaciones que para apreciaciones. Construyo y estimo un modelo EDGE para una economía pequeña y abierta donde emprendedores exportadores se encuentran sujetos a fricciones financieras y efectos de hojas de balance para explicar los hechos estilizados encontrados. Aunque estas fricciones reducen la expansión de las exportaciones ante movimientos en el tipo de cambio real, uso ejercicios computacionales para mostrar que no son suficientes para explicar los resultados empíricos.

Palabras Claves: Macroeconomía, Comercio Internacional, Sudden Stops

Clasificación JEL: F4, E6

Recibido:27/11/2019. Aceptado: 27/11/2020

\footnotetext{
${ }^{1}$ Department of Economics, Northwestern University, Address: 2211 Campus Dr, Evanston, IL 60208, United States. E-mail: santiagocamara2022@u.northwestern.edu. The original draft of this paper was first presented in November 2015. I would like to thank Martin Eichenbaum, Guido Lorenzoni, Giorgio Primiceri and Larry Christiano for their guidance and insightful comments. I would also like to thank attendees of the Argentinean Central Bank research seminar, attendees of Northwestern 501 seminar. Luis Cámara gave me insightful comments. I would like to acknowledge the support of Jose Luis Flor Toro, Cai Yong and Adriana Restuccia. Finally, I would like to thank the Becker Friedman Institute and the Monetary and Fiscal History of Latin America research project for funding this project. Finally, I thank two anonymous referees for their insightful comments.
}

Económica se encuentra bajo una licencia Creative Commons Atribución-NoComercial-SinDerivadas 4.0 Internacional 


\section{Introduction}

Understanding the dynamics of exports during and after financial crises is key for determining the speed of recovery from recessions. The capability of firms to shuffle sales from domestic markets to export markets will be key to prop up production while consumers and/or governments deleverage. While a large class of small open economy models do not take into account financial market or international trade frictions, and thus imply that goods can be effortlessly exported, the aggregate data shows a remarkable sluggish response of exports after episodes of significant stress, see Figure $1 .^{2}$

In this paper I study the role of financial frictions and adjustment costs on the dynamics of export after financial crises. To do so, I use highly detailed firm level data from two countries, Peru and Argentina, present new and motivating stylized facts, and study whether an estimated medium scale DSGE model can match the aggregate export dynamics after a financial crisis. ${ }^{3}$

I find that the sluggish response of exports after financial crises is primarily explained by a poor performance of incumbent exporters and a muted response of new exporting firms. Moreover, I estimate the response of firm level exports to the real exchange rate in different horizons and find that the elasticity is smaller to that usually assumed in the literature and seems to be asymmetric, larger in absolute terms for appreciations than for depreciations. Motivated by these stylized facts, I construct a DSGE model where exporting entrepreneurs borrow in foreign currency and thus are subject to both financial frictions and negative balance sheet effects.

I estimate that financial frictions and negative balance sheet effects do reduce the expansion of exports after depreciations of the real exchange rate but are not enough to explain both the sluggish response of aggregate exports observed after financial crises or the asymmetric response observed from the regression analysis.

\footnotetext{
${ }^{2}$ Figure 1 presents the detrended growth rates of exports around 18 episodes of Sudden Stop crises. Figure 1a presents the histogram of detrended growth rate one period after the crisis, while Figure $1 \mathrm{~b}$ presents the histogram of the annual average detrended growth rate two periods after the crisis. The details of the computation and identification of cases are described in Appendix B.

${ }^{3}$ In particular, I study focus my attention to two episodes of crisis: Peru 1998 and Argentina 2001.
} 
Figure 1. Exporting Firms

(a) Export Growth $t+1$

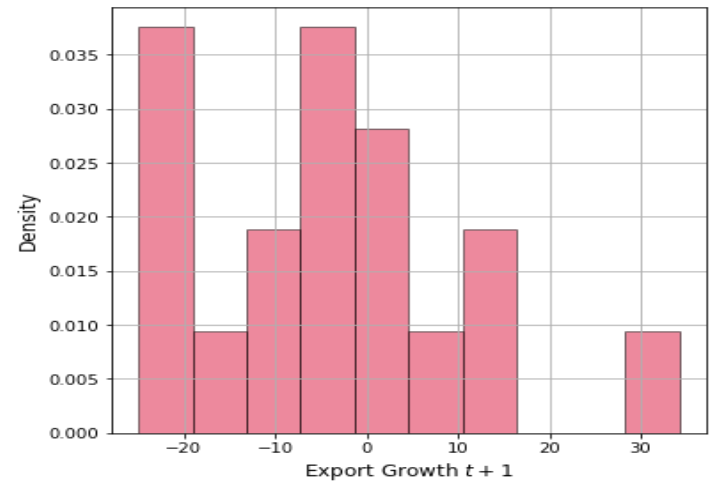

(b) Export Growth $t+2$

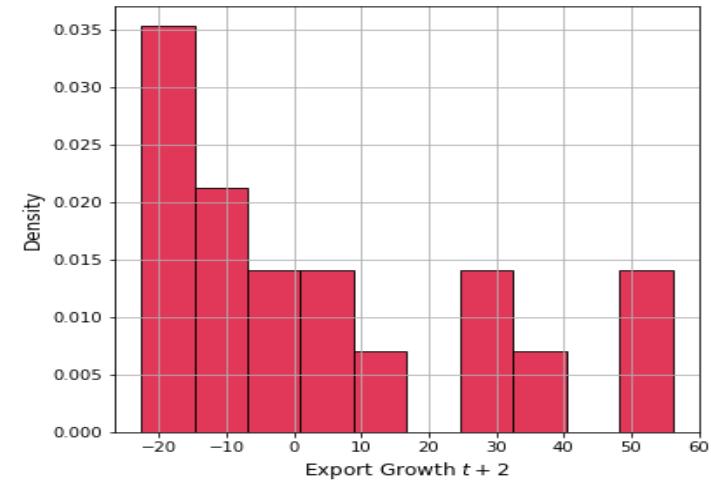

Source: Own elaboration based on Penn World Tables v9.1

To precisely analyze export dynamics during financial crises, I use the highly detailed firm level data for to emerging economies: Argentina and Peru. In particular, I study the firm level dynamics of exports in these economies during two episodes of financial crisis: Argentina's sovereign crisis in the years 2001 and 2002, and the sudden stop crisis of Peru in 1998. I show that aggregate exports either decrease or grow below the trend significantly during and after these crises although they are distinct in nature. ${ }^{4}$ This dynamic behavior of aggregate exports is explained by poor behavior by incumbent exporters, which took several years to go back to precrisis levels, and a minute contribution of entry of new exporting firms.

To quantitatively study the effects of exporting during episodes of financial crises and exchange rate depreciations I construct a medium scale dynamic and stochastic general equilibrium model with both an exportable and non-trade-able sectors. Moreover, a fraction of the exportable sector are subject to costly state verification frictions and balance sheet effects. Thus, in this model real exchange rate depreciations make exporting more profitable but at the same time increases the burden of entrepreneur's debt.

I study the model's ability to explain the data by an IRF matching procedure and several distinct computational exercises in which I analyze the response of exports to different aggregate shocks. I find that increasing the fraction of financially constrained exporting entrepreneurs reduces the response of aggregate exports.

This paper consists of 5 sections starting with the present introduction and a literature review in the next subsection. Section 2 describes the data and presents the main empirical findings of the paper. Section 3 describes a SOEDSGE model with financially constrained exporters. Section 4 estimates the model described in Section 3 and carries out computational exercises to test the model's ability to fit the data. Finally, Section 5 concludes.

\footnotetext{
${ }^{4}$ While both crises are episodes of significant financial stress and are usually identified as Sudden Stop crises by most of the literature (See Cavallo et al. (2015), the Peruvian 1998 crisis was a financial shock as a consequence of the East Asian crisis which started in 1997, and the Argentinean 2001 crisis included a financial crisis, a banking crisis, a balance of payment crisis and a sovereign default. However, although there are significant differences across the episodes under study, the emerging stylized facts are common across episodes and countries.
} 


\section{I.1. Related Literature}

This paper is related to a growing literature that analyzes the role of financial frictions in export dynamics and its potential aggregate implications. This growing literature has contributions both from the fields of international macroeconomics and international trade.

First and closest to the present paper is Kohn et al. (2020). In this paper, the authors analyze the role of financial frictions and balance-sheet effects in accounting for the dynamics of aggregate exports during episodes of large devaluations. Furthermore, the authors study the response of exports in Mexico during the aftermath of the 1994-1995 financial crisis. While the authors use a non-linear solution method to compute the model, which may better suited for the analysis of models with financial frictions, the model presented in this paper counts with multiple sectors and adjustment costs that are not taken into account in Kohn et al. (2020). Also, the present paper counts with detailed firm level data for several years, a feature not present in other papers in the literature of international macroeconomics.

There are several other papers in the literature of international macroeconomics that address the role of financial frictions in explaining aggregate export dynamics. Alessandria et al. (2013) study the dynamics of aggregate exports after episodes of large devaluations and construct an heterogeneous firm model subject to sunk and fixed costs of exporting. Consequently, financial crises associated with high interest rates lead to low export growth as they deter the entry of new exporting firms. Also, Lin et al. (2018) present evidence that countries with higher volatility of the real exchange rate exhibit lower export growth. The authors construct a DSGE model where the exportable sector is subject to financial frictions in order to match their new stylized fact. The main contribution of the present paper is that by exploit firm level data I am able to dis-entangle aggregate exports into different margins and accordingly construct a macroeconomic structural model.

Next, there are several papers who have studied the dynamics of trade and the elasticities of exports to the real exchange rate from an international trade perspective. Berman et al. (2012) estimate the elasticity of exports to the real exchange rate for French firms allowing to different elasticities depending on firm size. The authors find that bigger firm react to depreciations by increasing their mark-ups and show a small increase in the quantities exported than smaller firms. Chatterjee et al. (2013) estimate the export elasticity to exchange rate and allow for the elasticity to vary across firms' products. The authors find that quantities exported react less for products that are higher in firms ranking, i.e., firms' top export products expand less after exchange rate depreciations than less popular products.

Additionally, there are several papers which use micro-level data to decompose the aggregate dynamics of international trade during economic crises. An example of this literature is Gopinath and Neiman (2014) which uses detailed import firm level data for Argentina's 2001 crisis. The authors find that although imports collapsed by 70 percent between 2000 and 2002, the entry and exit of firms or products at the country level played a small role. The within-firm churning of imported inputs, however, played a sizeable role and explain most of aggregate dynamics. The authors construct a partial equilibrium model of importing firms subject to fixed costs in which domestic and intermediate varieties are imperfect substitute. Thus, an increase in the exchange rate leads to lower intermediate inputs being imported and, consequently, an endogenous drop in firms' productivity. The present paper also uses firm level data to analyze the dynamics of international trade during Argentina's 2001 crisis but instead of focusing on imports it seeks to 
shed light on the aggregate behavior of exports. Furthermore, although I do not take into account possible endogenous consequences of falling imports (such as drops in productivity), I construct a general equilibrium in which model to study how financial frictions in the exporting sector may impact aggregate dynamics.

\section{Data \& Empirical Findings}

In this section of the paper I describe the main datasets used across the paper. In particular, I describe in detail the firm level datasets used to study the financial crises of Argentina 2001 and Peru 1998. Furthermore, I decompose the dynamics of aggregate exports into different margins to show the role of incumbent and new exporting firms in shaping aggregate export dynamics. Finally, I follow the literature in international trade to estimate the elasticity of exports to the real exchange rate, but allow for an asymmetric response according to the sign of the change in the exchange rate.

\section{II.1. Data Description \& Dynamic Decomposition}

The main focus of this papers is to present a rich data focused on the analysis on the macroeconomics and microeconomics mechanism of adjustment during financial crises and present new stylized facts. In this section of the paper, I briefly describe the data sets used across this paper.

First, I describe the firm level data coming from Argentina. I use a dataset containing Argentine customs data coming from Aduana Argentina. ${ }^{5}$ Our data are collected from export shipping manifests by the customs agency. The time-frame vary across countries but I count with detailed information for each trade shipment, including a time invariant firm identifier, the date of declaration, the destination country, the weight and value of the good, along with detailed information at the 6-digit HTS classification. ${ }^{6}$ I count with data from 1994 to 2018 at the quarterly level. In terms of cleaning of the variable, I keep all observations for which I have a valid destination country and a valid good classification number using the World Bank's WITS classification to generate concordances across time.

Second, I describe the firm level data coming from Peru. The data employed for Peru are transaction-level customs data for the period 1993-2009. The data was collected by the Trade and Integration Unit of the World Bank Research Department, as part of their efforts to build the Exporter Dynamics Database described in Fernandes et al. (2016). ${ }^{7}$ The dataset contains information on the firm identification, value exported, quantities exported measured in kilos, HS6 good classification and the country of destination.

Finally, I describe the construction of the bilateral real exchange rates used in my econometric exercises. Data on nominal exchange rates of different currencies with respect to the dollar are

\footnotetext{
${ }^{5}$ There are several private vendors that compile this data, such as Datamyne and Nosis

${ }^{6}$ The present data set counts with an eleven digit and a letter classification, allowing us to distinguish between goods at a 12 digit level.

${ }^{7}$ The sources for the data for each country are detailed at http://www.worldbank.org/en/research/brief/exporter-dynamics-database.
} 
taken from the IMF-IFS dataset. Furthermore, I use the IMF-IFS as a source of the CPI of all destination countries in my sample. With respect to the CPI of Argentina I use INDEC's IPCGBA CPI between 1994 to 2006 included and from 2007 onward I use the CPI constructed by Consultora GBIE.

I start my analysis of the firm level datasets by studying the dynamics of the number of exporting firms close to the episodes of severe financial stress. To do so, I create indexes of exporting firms equal to a 100 in the year of the crisis. ${ }^{8}$ Figures 2 and 3 present the results for total exporting firms and for non-commodity exporting firms. ${ }^{9}$ First, from these figures it is clear that both for a sovereign crises and for a Sudden Stop style crisis, the severe financial conditions lead to firm exit from exports markets. This can be seen from a lower number of exporting firms during the year of the crisis and/or on the year that followed the crisis. Furthermore, the number of exporting firms tend to take between two and or three years to return to pre-crisis levels. This is evidence that the extensive margin of international trade, i.e., the entry and exit of exporting firms might not play a significant role in explaining the dynamics of aggregate exports in the short run. ${ }^{10}$

\section{Figure 2. Exporting Firms}

(a) Argentina 2001

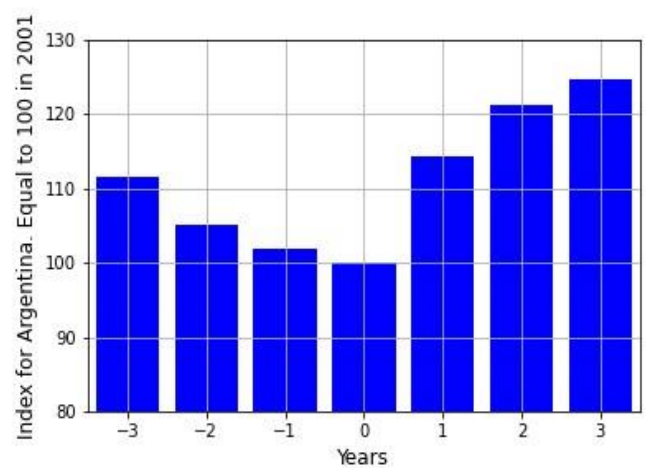

(b) Peru 1998

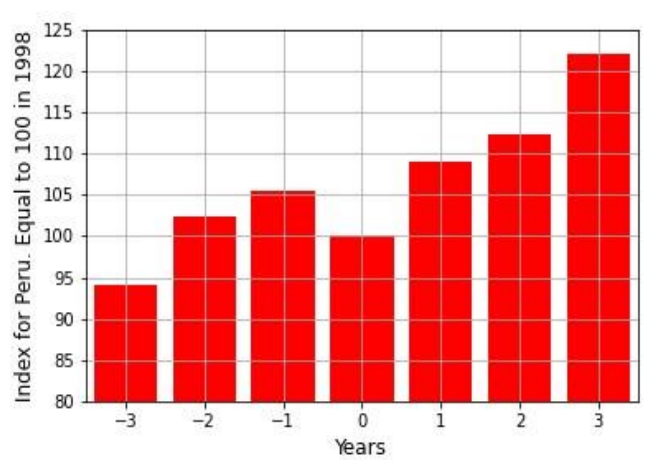

Source: Own elaboration based on data from Aduana Argentina and Exporter Dynamics Database

\footnotetext{
${ }^{8}$ For instance, I normalize the index equal to 100 for Argentina in the year 2001, and 100 for Peru in the year 1998.

${ }^{9}$ In order to identify non-commodity exporting firms I drop the observations in which the exporting manifest identifies the HS6 good classification code coming from chapters HS 27 or below. Thus, if a firm exports a commodity and a non-commodity good I identify that firm as a non-commodity exporter. Consequently, this definition of noncommodity exporting firm is not strict. Changing to tighter definitions do not alter the results significantly, and the results are available upon request.

${ }^{10}$ These results are in line with the results presented by Eaton et al. (2008) who carry out a more detailed analysis of the margins of trade for exporting firms in Colombia.
} 
Figure 3. Exporting Firms - Non-Commodities

\section{(a) Argentina 2001}

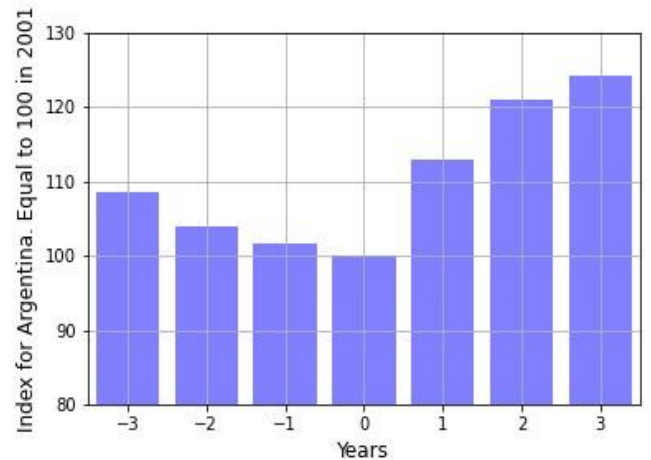

(b) Peru 1998

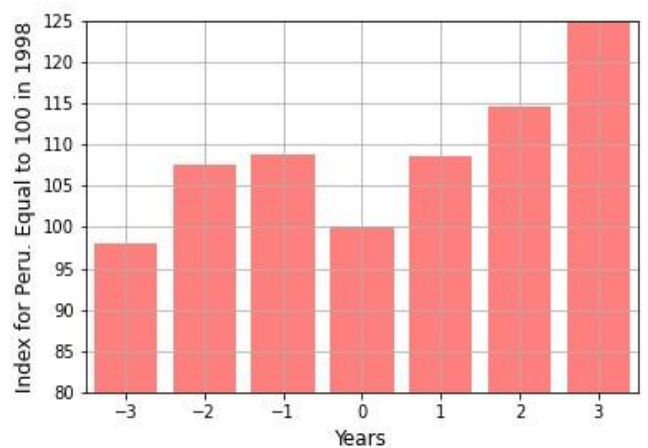

Source: Own elaboration based on data from Aduana Argentina and Exporter Dynamics Database

Next, I decompose the dynamics of aggregate exports between firms alive during the crisis, firms that exit when the crisis hits and firms that enter after the crisis. I follow the decomposition proposed by Gopinath and Neiman (2014) and decompose the aggregate dynamics of exports in intensive and extensive margins. I define the intensive margin of exports as the value of exports explained by firms alive during the year of the crisis. Thus, the extensive margin of exports is the value of exports explained by firms that are not actively exporting during the year of the crisis. Note that if a firm is active before the crisis and exits during the year of the crisis, the comparison of the extensive margin will tell us how much of the variation in exports before and during the crisis is explained by firms exiting export markets. On the other hand, this definition of the extensive margin after the crisis provides me with a measure of how much of export growth after the crisis is explained by the entry of exporting firms that were not alive during the crisis. ${ }^{11}$

${ }^{11}$ Note that this definition of the extensive margin does not focus only in new exporting firms. In other words, if a firm is exporting in year $t=-1$, does not export in $t=0$, but re-enters export markets in period $t=1$, it will be counted as part of the extensive margin both before and after the crisis. 
Figure 4. Export: Intensive vs Extensive Margin

(a) Argentina 2001

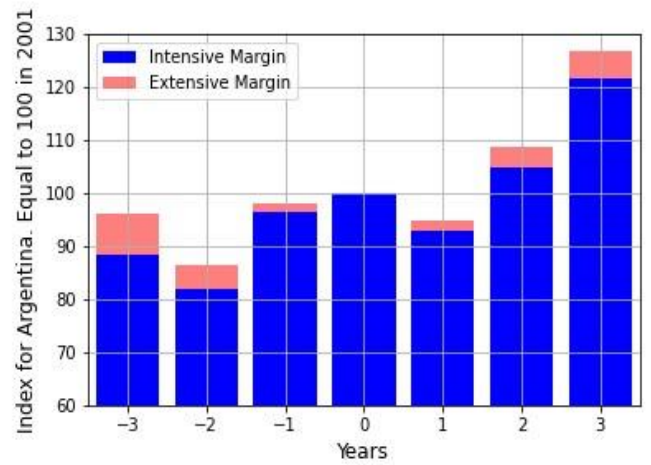

(b) Peru 1998

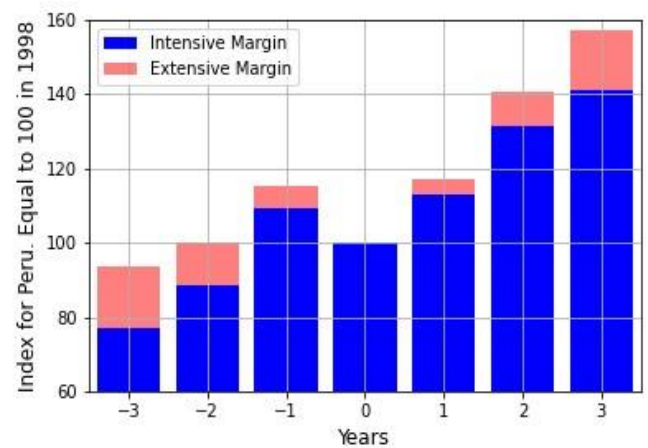

Source: Own elaboration based on data from Aduana Argentina and Exporter Dynamics Database

Figure 5. Exports: Intensive vs Extensive Margin. Non - Commodities

(a) Argentina 2001

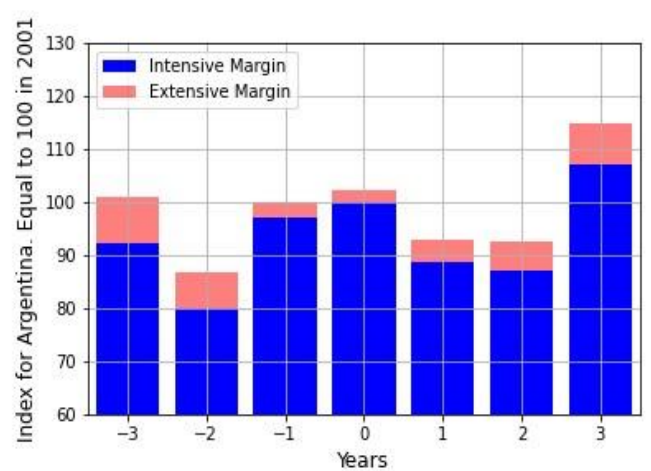

(b) Peru 1998

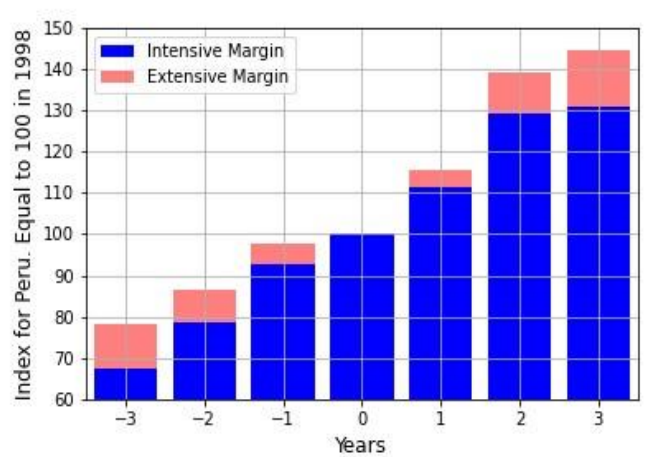

Source: Own elaboration based on data from Aduana Argentina and Exporter Dynamics Database

The decomposition of exports for both total exports and non-commodity exports are carried out in Figures 4 and 5 respectively. The first thing to notice from these figures is that there exports definitely show a poor performance during and after the episodes of financial crises. For instance, total exports decrease upon impact and recover pre-crisis levels two years after the crisis. ${ }^{12}$ For instance, non-commodity exports for Argentina recover pre-crisis levels three years after the crisis. However, most noticeably is that around the episodes of severe financial stress the extensive margin seems to play a small role in explaining the aggregate dynamics of exports. In other words, the fall in exports explained through firms exiting during the crisis are not the main driver of export decline. Also, the entry of new exporting firms after the crisis do not seem to be the main driver of the export recovery after the crisis. Consequently, it is the intensive margin of trade, the export performance of incumbent exporting firms, which explains the aggregate dynamics of exports on the aftermath of financial crises.

${ }^{12}$ The only exception is non-commodity exports for Peru how show a mark slowdown during the year of the crisis. 
To sum up, the results presented above highlight that the aggregate dynamics of exports during and in the aftermath of financial crises are primarily explained by poor export performance by firms that were already exporting before the crisis. Although the number of exporting firms tend to decrease during crises and only slowly recover years after, the contribution of exit and entry is only marginal. Thus, a theory that seeks to explain the dynamics of aggregate exports during a financial crisis should be able to explain behavior of incumbent exporting firms.

\section{II.2. Econometric Exercises}

In this subsection of the paper I present the main econometric exercise of the paper in which I compute measures of the elasticity of exports to the real exchange rate using detailed firm level data from Argentina.

The empirical exercise that I carry out across this section is that of impulse response functions using a Local Projection Method presented by Jordà (2005) for panel data sets. Briefly, this method runs a regression of the form

$$
y_{t+h}=\beta_{0}^{h} y_{t}+\cdots+\beta_{p}^{h} y_{t-p}+F E_{t}+u_{t+h}
$$

for different time horizons $h$. The coefficient of interest is $\beta_{0}^{h} y_{t}$ for each period $h$, while $y_{t-j}$ for $j=1, \ldots, p$ act as controls and $F E_{t}$ are fixed effects I will specify later. The standard errors for each coefficient are computed using robust standard error. Furthermore, I will run the empirical exercises conditioning on the sign of the real exchange rate shocks. In other words, I will compute the exchange rate elasticity of exports in period $h$ with respect to the real exchange rate in period $t$ conditioning if the change in this variable is positive (depreciation) or negative (appreciation).

Next, I need to specify the level of observation and at what time frequency I will run my empirical specification. First of all, I follow Berman et al. (2012) and run my econometric exercise using exports at the firm-product-destination level. Furthermore, given that every 5 years the classification of goods is updated and that there is no concordance for the Argentinean 11 digit good classification I use HS 6 good classification. As I stated above, I use the World Bank's WITS concordance tables. Also, as in Berman et al. (2012), I will use firm-destination fixed effects and time fixed effects. Finally, in terms of the frequency of my empirical exercises will take place at the quarterly frequency. I choose this time frequency in order to exploit differences in real exchange rate across different destinations that might average out at the annual frequency, and also because firm level exercises that at annual frequencies are prone to aggregation measure problems. ${ }^{13} \mathrm{I}$ also follow Berman et al. (2012) and run the empirical regressions using quantities exported.

Figure 6 presents the results of the impulse response exercise for quantities exported at the firm-destination-product for a $1 \%$ change in the bilateral real exchange rate with $95 \%$ confidence intervals in shaded area. Note that for ease of comparison, the IRF for the appreciation elasticity Figure 6 plots the negative response. From Figure 6 it is clear that the elasticity of exports to the real exchange rate differs substantially depending on the sign of the shock. The elasticities computed for real depreciations are significantly below the elasticities computed for real appreciations for virtually all time horizons. As a robustness check, I present the same exercise

${ }^{13}$ Annual empirical exercises might be subject to the partial year effect, see Eaton et al. (2008) for details 
for Peru in Figure 7 and focus on the response of the quantities exported to positive and negative variations in the real exchange rates. First, Figure 7 shows that the exchange rate elasticity of exports to the exchange rate is remarkably lower for Peruvian firms than for Argentinean firms. ${ }^{14}$ Beyond the difference in magnitude, for the first half of the horizon, the elasticity of exported quantities to appreciations is between $50 \%$ and $80 \%$ greater than the elasticity of exports to depreciations. This asymmetry might arise from different reasons. First of all, given the lumpy nature of international trade ${ }^{15}$, it would be surprising for quantities exported to react rapidly to changes in the bilateral real exchange rate. However, it might be the case that prices react relatively faster than quantities. ${ }^{16}$ At the same time, it could be the case that the bilateral real exchange rate does not play a significant role in terms of pricing if the invoicing is made in US dollars. For instance, if an Argentinean firm exports to India invoicing the product in US dollars and the peso depreciates with respect to the US dollar but the peso remains relatively stable with respect to the Indian rupee, it could be the case that on impact the price falls in dollars

\section{Figure 6. Impulse Response Function of Quantities Exported}

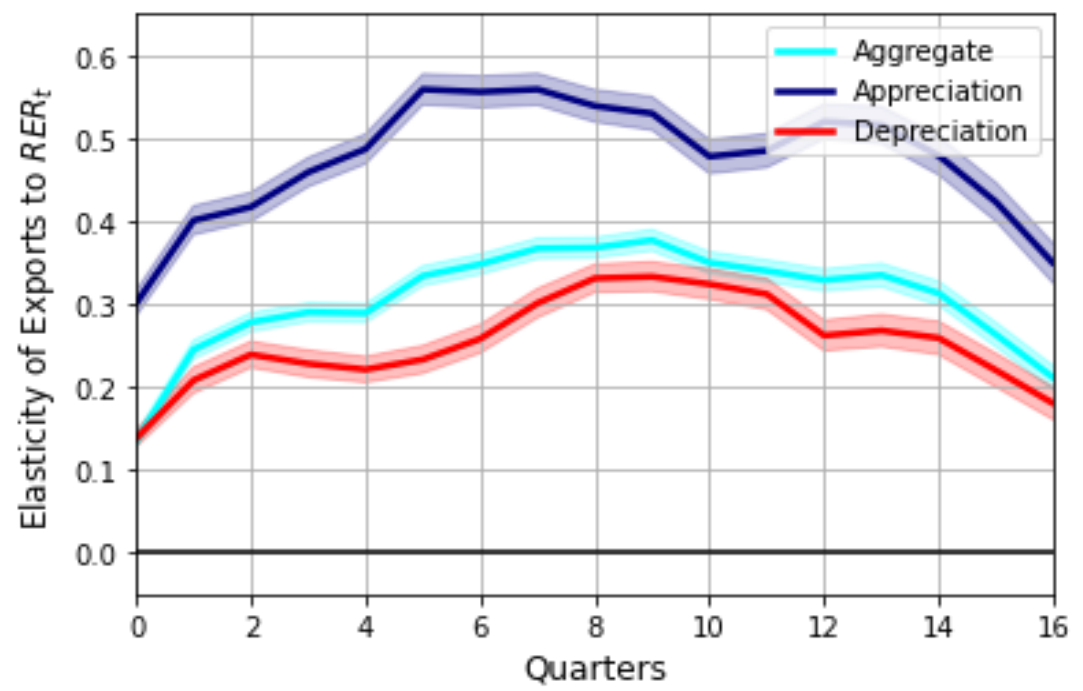

Source: Own elaboration based on data from Aduana Argentina, Exporter Dynamics Database, data on nominal exchange rates and CPI from IMF-IFS, INDEC's IPC-GBA CPI between 1994 to 2006 included and the CPI of Argentina constructed by Consultora GBIE from 2007 onward.

${ }^{14}$ This stylized fact might be explained by the composition of the export bundles. Peru's export bundle is primarily explained by mineral commodities which exports depend more on world demand than of the bilateral exchange rate. However, to study the differences in exchange elasticities across different goods is beyond the scope of this paper. Another potential reason for the difference in magnitudes

${ }^{15}$ See, Kohn et al. (2016) for a description of the intricate and time consuming process of exporting.

${ }^{16}$ An earlier version of this paper had IRF analysis for quantities exported. However, given that custom agents measure quantities in terms of weight, introduced measurement errors and statistical noise that lead to me to discard these results from a final version of the paper. 
Figure 7. Impulse Response Function of Quantities Exported

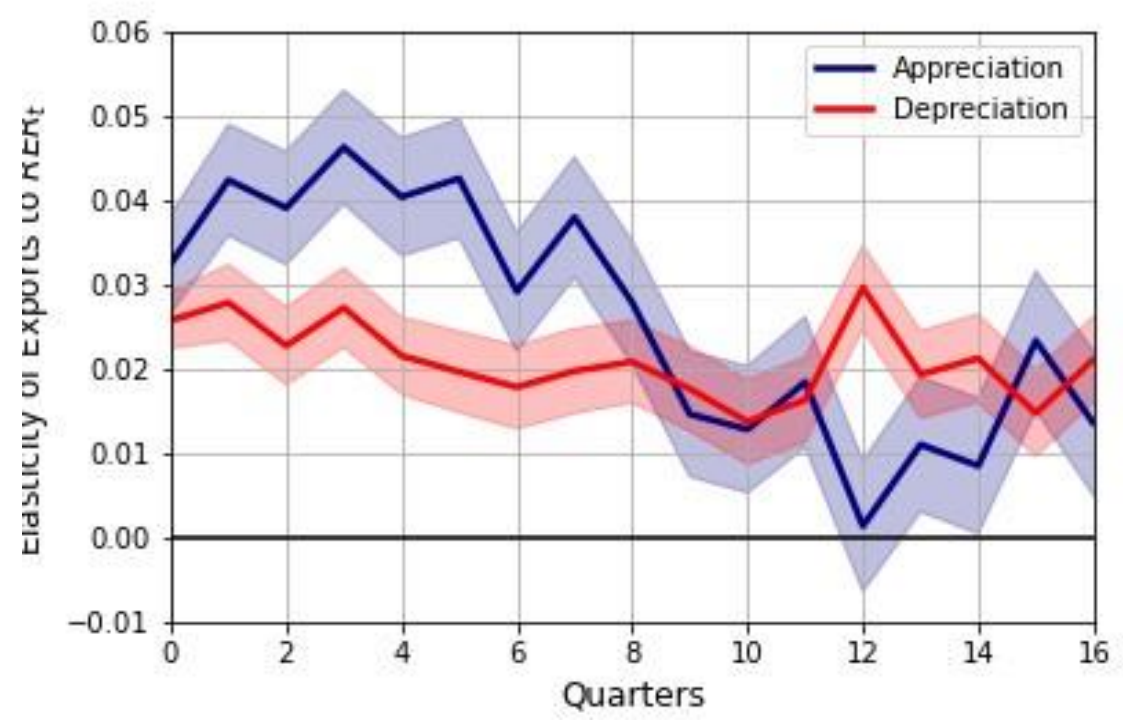

Source: Own elaboration based on data from Aduana Argentina, Exporter Dynamics Database, data on nominal exchange rates and CPI from IMF-IFS, INDEC's IPC-GBA CPI between 1994 to 2006 included and the CPI of Argentina constructed by Consultora GBIE from 2007 onward.

\section{A More Structural Analysis}

In this section I take a medium scale small open economy model as the one presented in Lin et al. (2018). I solve the model using a second order perturbation method that allows for asymmetric IRFs and estimate the model using an IRF matching process. Finally, I carry out exercises of IRFs starting from different points in the ergodic distribution of the model. Given the length of the model I focus on describing the main features and leave details to the Appendix A.

The model a dynamic stochastic general equilibrium model that consists of two-sectors, tradable and non-tradable, subject to credit constraints. Firms in both sectors use capital and labor as factors of production and sell goods to domestic and foreign markets, respectively.

\section{III.1 Households}

The representative household in this economy has preferences given by

$$
\mathbb{E}_{0} \sum_{t=0}^{\infty} \beta^{t}\left[\ln \left(C_{t}\right)-\eta \frac{L_{t}^{1+\psi}}{1+\psi}\right]
$$

where $C_{t}$ is a consumption bundle, and $L_{t}$ is labor supply. The consumption bundle $C_{t}$ is a CobbDouglas composite of the non-tradable and imported goods 


$$
C_{t}=\frac{1}{a^{a}(1-a)^{1-a}} C_{N, t}^{a} C_{F, t}^{1-a}
$$

where the consumer price index is $P_{t}=P_{N, t}^{a} P_{F, t}^{1-a}$, where $P_{N, t}$ and $P_{F, t}$ are the prices of the nontradable and imported goods respectively.

Households have access to both domestic and international capital markets. Trade in international bonds is subject to small portfolio adjustment costs. These type of adjustment costs are necessary to avoid debt processes that follow unit-root problems. ${ }^{17}$ In particular, if a household borrows an amount $D_{t+1}$, the portfolio adjustment cost is

$$
\frac{\psi D}{2}\left(D_{t+1}+\bar{D}\right)^{2}
$$

where variables are denominated in terms of the composite consumption good and where $\bar{D}$ is the steady state level of debt. Households can choose to save or borrow from international markets at interest rate $i_{\mathrm{t}}^{*}$, or save or borrow from domestic markets at interest rate $i_{t}$. Furthermore, households own the firms in the tradable sector that are unconstrained or do not face credit constraints.

The representative agent's budget constraint:

$$
\begin{aligned}
& P_{t}\left(C_{t}+\left(1-S\left(I_{t}, I_{t-1}\right)\right) I_{t}+\frac{\psi D}{2}\left(D_{t+1}-\bar{D}\right)^{2}\right) \\
& =W_{t} L_{t}+R_{t} K_{t}+D_{t+1}+B_{t+1}-\left(1+i_{t}^{*}\right) D_{t}-\left(1+i_{t}\right) B_{t}+\Pi_{t}
\end{aligned}
$$

where $W_{t}$ is the wage rate, $R_{t} K_{t}$ is capital rental income from capital rented to both the nontradable and the tradable sectors (for the unconstrained firms), $B_{t}$ and $D_{\mathrm{t}}$ represent debt in domestic and international markets. I assume the function that governs the investment adjustment costs is $S\left(I_{t}, I_{t-1}\right)=I_{t} \frac{\phi_{j}^{I}}{2}\left(\frac{I_{t}^{c}}{I_{t-1}^{c}}-1\right)^{2}$ for $j \in\{X, N\}$. This implies that investment is sector specific and the adjustment costs are also sector specific. Given that the optimality conditions are relatively standard they are presented in the Appendix.

\section{III.2. Non-Tradable Sector}

The non-tradable sector is perfectly competitive. The production function is Cobb-Douglas in capital and labor

$$
Y_{N, t}=\left(\frac{K_{N, t}}{\alpha_{N}}\right)^{\alpha_{N}}\left(\frac{L_{N, t}}{1-\alpha_{N}}\right)^{1-\alpha_{N}}
$$

where $K_{N, t}$ and $L_{N, t}$ are the capital and labor employed in the non-tradable sector, respectively, and $\alpha_{N}$ represents the share of capital in production.

${ }^{17}$ See Schmitt-Grohé and Uribe (2003) 


\section{III.3. Tradable Sectors}

The tradable sector contains a unit interval $[0,1]$ of firms indexed by $j$. Each firm $j$ produces a differentiated traded good, which is an imperfect substitute of each other in the production function of composite goods produced by a representative competitive firm. I assume that a fraction of firms are subject to credit constraints. The unconstrained firm's problem is completely standard as for the non-traded good.

For the credit constrained sub-sector, there is an infinitely lived entrepreneur with a mass of 1 who is seeking export opportunities. I assume that entrepreneurs face financial constraints due to limited enforcement in the spirit of Kiyotaki and Moore (1997). The production of the composite exportable good, $Y_{X}$, is given by

$$
Y_{X, t}=\left[\int_{0}^{k}\left(Y_{X, t}^{c}(j)\right)^{\frac{\lambda-1}{\lambda}} d j+\int_{k}^{1}\left(Y_{X, t}^{u}(j)\right)^{\frac{\lambda-1}{\lambda}} d j\right]^{\frac{\lambda}{\lambda-1}}
$$

where $\lambda$ is the elasticity of substitution between differentiated traded goods, $\kappa$ is the weight of credit constrained goods in the aggregation of tradable goods.

Next, I describe in more detail the entrepreneur's problem. At the beginning of each period, an entrepreneur enters with predetermined capital. After production at the end of each period, the entrepreneur must decide how much capital to purchase for the next period and how much loan to borrow from households. When she borrows from households, an entrepreneur has a probability of defaulting on the loan, and the maximum amount a household can recover is a fraction $\phi$ of the time $t$ nominal value of the value of its enterprise stock in the next period, $V^{f}\left(B_{t}^{c}, K_{X, t}^{c}\right)$. To make sure that the entrepreneur has a need for external financing in the long run, I assume that each period there is an exogenous probability $\xi$ the entrepreneur will die and the same probability that there is a newborn. Upon her death, the entrepreneur will transfer all of her wealth to the newborn and will stop consumption. The value of the firm is defined as:

$$
V^{f}\left(B_{t}^{c}, K_{X, t}^{c}\right)=\max _{B_{t}^{c}, K_{t}^{c}, L_{X, t}^{c}} d_{X, t}^{c}+\beta(1-\xi) \mathbb{E}_{t} V^{f}\left(B_{t+1}^{c}, K_{X, t+1}^{c}\right)
$$

where

$$
\begin{gathered}
d_{X, t}^{c}=P_{X, t}^{c} Y_{X, t}^{c}-W_{t} L_{X, t}^{c}+I_{t}^{c}-I_{t}^{c} \frac{\phi^{I}}{2}\left(\frac{I_{t}^{c}}{I_{t-1}^{c}}-1\right)^{2}+B_{t+1}^{c}-(1 \\
\left.+i_{t}\right) B_{t}^{c}
\end{gathered}
$$

is the firm's dividend at the end of period $t$. Also, $Y_{X, t}^{c}$ represents output, $P_{X, t}^{c}$ represents the price of the product and $L_{X, t}^{c}$ and $K_{X, t}^{c}$ represent labor and capital respectively. Finally, $I_{t}^{c}$ represents investment and $B_{t}^{c}$ represents the amount of debt. The entrepreneur's preferences are logarithmic with respect to consumption, $\ln C_{t}^{e}$, where $C_{t}^{e}$ represents the entrepreneur's consumption. Given the firm's value function, the entrepreneur maximizes utility by solving the following Bellman equation

$$
V\left(B_{t}^{c}, K_{X, t}^{c}\right)=\max _{C_{t}^{e}, B_{t+1}^{c}, K_{X, t+1}^{c}, L_{X, t}^{c}} \ln C_{t}^{e}+\beta(1-\xi) \mathbb{E}_{t} V\left(B_{t+1}^{c}, K_{X, t+1}^{c}\right)
$$


subject to the following budget constraint

$$
\begin{aligned}
P_{t}\left(C_{t}^{e}+K_{X, t+1}^{c}\right) & +\left(1+i_{t}\right) B_{t}^{c} \\
= & P_{X, t}^{c} Y_{X, t}^{c}-W_{t} L_{X, t}^{c}+(1-\delta) P_{t} K_{X, t}^{c}+B_{t+1}^{c}
\end{aligned}
$$

and the following credit constraint

$$
B_{t+1}^{c} \leq \phi \mathbb{E}_{t} V^{f}\left(B_{t+1}^{c}, K_{X, t+1}^{c}\right)
$$

where $\phi$ is the fraction of the firm value that can be used as collateral. Although the Appendix A presents the optimality conditions, the key equation that describes the entrepreneur's behavior is

$$
\beta(1-\xi) \mathbb{E}_{t}\left[\frac{C_{t}^{e} P_{t}}{C_{t+1}^{e} P_{t+1}}\left(\frac{P_{t+1}}{P_{t}}\left(\frac{R_{t+1}^{c}}{P_{t+1}+1-\delta}-\phi\left(1+i_{t+1}\right) \Theta_{\mathrm{t}}\right)\right)\right]=1-\phi \Theta_{t}
$$

where $R_{t+1}^{c}$ is the rate of return on capital given by

$$
R_{t+1}^{c}=\frac{\lambda-1}{\lambda} P_{X, t+1}^{c} \frac{\partial Y_{X, t+1}^{c}}{\partial K_{X, t+1}^{c}}
$$

and $\Theta_{t}$ is given by

$$
\Theta_{\mathrm{t}}=\frac{\mathbb{E}_{t}\left[\frac{P_{t+1}}{P_{t}}\left(\frac{R_{t+1}^{c}}{P_{t+1}}+1-\delta\right)\right]}{1+\phi \mathbb{E}_{t}\left[1+i_{t+1}\right]}
$$

Note, that I have not defined the real exchange yet. In this simple two-sector model economy the real exchange rate, $e_{t}$, will be given by the ratio of the index price of exportable goods to the price of the imported good

$$
e_{t}=\frac{P_{X, t}^{*}}{P_{F, t}}
$$

I assume that the real exchange follows an $A R(1)$ process in logs

$$
\ln e_{t}=\left(1-\rho_{e}\right) \ln (\bar{e})+\rho_{e} \ln e_{t-1}+\sigma_{e} \epsilon_{t}
$$

where $\bar{e}$ is the steady state value of terms of trade, the persistence coefficient $\rho_{e} \in[0,1]$, and the innovation $\epsilon_{t}$ is i.i.d. Gaussian shock with zero mean and standard deviation equal to one. Note that in this simple set-up, a shock to the real exchange rate is a shock to terms of trade. A positive terms of trade shock is equivalent to a productivity shock to the tradable or exportable sector, which leads to real exchange rate appreciation. 


\section{III.4. Equilibrium and Aggregation}

In equilibrium the demand for non-tradable good markets must clear. This implies that demand for non-tradable goods has to be equal to the production of non-tradable goods. In other words, if I define $Y_{N, t}=a \frac{P_{t} Z_{t}}{P_{N, t}}$, where $Z_{t}$ is the total demand for aggregate goods and is given by

$$
Z_{t}=C_{t}+I_{t}+\left(C_{t}^{e}+I_{X, t}^{c}\right)+\frac{\psi D}{2}\left(D_{t+1}-\bar{D}\right)^{2}
$$

where $C_{t}+I_{t}$ represent the consumption and investment in capital of the representative household, $\left(C_{t}^{e}+I_{X, t}^{c}\right)$ represent the consumption and investment of the entrepreneurs in the tradable or exportable sector, while the last term represent the debt portfolio adjustment costs.

In terms of the markets for factors, given that there are no frictions on the labor markets, in equilibrium wages must equalize across sectors and labor demand must equalize labor supply

$$
L_{N, t}+L_{X, t}^{c}+L_{X, t}^{u}=L_{t}
$$

where $L_{N, t}$ is labor demand by the non-tradable sector and $L_{X, t}^{c}$ and $L_{X, t}^{u}$ are labor demand by the constrained and unconstrained tradable sectors. At the same time, equilibrium must have $K_{t}=$ $K_{N, t}+K_{X, t}^{u}$. Also, in equilibrium, $B_{t}+B_{t}^{c}=0$. These equilibrium conditions imply that the aggregate budget constraint for the economy as a whole can be written as:

$$
P_{t} Z_{t}+\left(1+i_{t}^{*}\right) D_{t}=P_{t} Y_{t}+D_{t+1}
$$

where $Y_{t}=\frac{P_{N, t} Y_{N, t}+P_{X, t} Y_{X, t}}{P_{t}}$ is the total output of this small open economy.

To close the model I introduce extra exogenous processes so that the model fits better the data. Given that the terms of trade also capture a productivity shock, I choose to introduce two additional shocks: I assume that both the international interest rate and the probability of death for entrepreneurs follow an $A R(1)$ process. Interest rate shocks such as $i_{t}^{*}$, are common in the literature in international macroeconomics, and are usually one of the main sources of volatility of aggregate fluctuations. A shock to the probability of death of the entrepreneurs can be interpreted as a shock to the discount factor of the constrained investors in this economy. A positive shock to $\xi$ reduces $\beta(1-\xi)$ and the entrepreneur's stochastic discount factor as a whole, leading to changes in aggregate demand orthogonal to fundamentals. ${ }^{18}$

The equilibrium is defined as follows; given the stochastic process for $\left\{e_{t}, i_{t}^{*}, \xi_{t}\right\}$, an equilibrium is an allocation of consumption $\left\{C_{t}, C_{t}^{e}\right\}$, labor supply and labor demand $\left\{L_{t}, L_{N, t}, L_{X, t}^{u}, L_{X, t}^{c}\right\}$ levels of aggregate demand at the economy wide level $\left\{Z_{t}\right\}$, and levels of production $\left\{Y_{t}, Y_{N, t}, Y_{X, t}, Y_{X, t}^{u}, Y_{X, t}^{c}, Z_{t}\right\}$, capital stocks $\left\{K_{N, t}, K_{X, t}^{u}, K_{X, t}^{c}\right\}$ and investment $\left\{I_{t}, I_{X, t}^{c}\right.$ \} , debt $\left\{D_{t}\right\}$ and prices $\left\{P_{t}, P_{N, t}, P_{F, t}, P_{X, t}, P_{X, t}^{u}, P_{X, t}^{c}, R_{t}, i_{t}, W_{t}\right\}$ that satisfy household's, firms' and entrepreneur's optimization conditions and market clearing conditions.

\footnotetext{
${ }^{18}$ Another way to think about this type of shock is a demand shock or a shock to animal spirits.
} 


\section{Estimation \& Computational Exercises IV.1.DSGE Estimation}

In this subsection of the paper I present the calibration and estimation of the DSGE model presented in the previous section. I divide the set of the parameter into two distinct subsets. A first subset of the parameters will be calibrated while the second subset of parameters will be estimated using a Matching of Impulse Response Function process using the empirical IRFs presented in Section 2.

The calibration procedure sets most of the parameters that govern the behaviour of the representative household and of the non-tradable and unconstrained tradable sector. The time period of the model is quarterly frequency. The discount factor $\beta$ is calibrated to match an international interest rate close to an annual $8.5 \%$ rate, the depreciation rate is calibrated to annual rate of $12 \%$ and is taken from Coremberg (2007). The share of capital in both tradable and nontradable sectors come from averaging out the share in income of factors across different sectors with data coming from Coremberg (2007) and Coremberg (2009). The parameter $\eta$ is chosen to 2.5 which leads households to spend $45 \%$ of their hours working which is a standard value in the literature ${ }^{19}$ for example. The parameter $\psi$ is set to 0.8 , so that the supply elasticity of labour is 1.25 which is also a value used frequently in the literature. I also calibrate the value of the trade balance in steady state equal to $2.5 \%$ of GDP, which comes from Garcia-Cicco et al. (2010). I calibrate the importance of the non-tradable goods in the consumption composite to be equal to $80 \%$. Although this value is greater than the usual values of the literature, for example SchmittGrohé and Uribe (2003), it seems plausible given that Argentina is relatively less open than other emerging market economies. ${ }^{20}$ The probability of death of entrepreneurs in steady state, $\bar{\xi}$, is calibrated to $0.05 / 4$, so that the average work time of an entrepreneur is 20 years. The parameter $\psi_{D}$ is calibrated to 0.1. Debt dynamics in Argentina are somewhat difficult to match in a model with no default. Furthermore, given that the solution method used is a high-order approximation to the value function, a relatively low value ( 0.001 for example) might lead to explosive dynamics. ${ }^{21}$ I settle for a large value to capture a relatively elastic response of the cost of debt to deviations from the steady state level. I choose the parameters that govern the process of the international interest rate for it to be significantly persistent ${ }^{22}$ and a standard deviation of 25 basis points. Finally, I choose parameters for the law of motion of $\xi_{t}$ such that the process yields similar dynamics than that of Albuquerque et al. (2016) which introduces a similar demand shock but in a different context.

\footnotetext{
${ }^{19}$ See Lin et al. (2018)

${ }^{20}$ Another way to justify the great importance of non-trade-able sector in the consumption is that under INDEC's CPI methodology (available at www.indec.gob.ar), $41 \%$ of the consumption bundle are services and most of the goods consumed (such as apparel) are not internationally traded (mostly because of tariffs and non-tariff barriers). Another way to justify this value for the importance of non-trade-able goods in the consumption bundle is that imports of consumption goods are approximately $3 \%$ of GDP on average. For instance, in the year 2019, imports where $15 \%$ of GDP and using the BEC good classification, consumer goods and foods and beverages represented less than $15 \%$ of total imports. This yields to consumer goods being equal to imports of consumer final goods approximately $2.25 \%$ of GDP

${ }^{21}$ This is the case if I do not recur to pruning techniques

${ }^{22}$ See Uribe (2018) where the author finds an almost unit root process for the Federal Funds Rate.
} 
Table 1. Calibrated Parameters

\begin{tabular}{c|c|c}
\hline Parameter & Parameter Description & Calibrated Value \\
\hline$\beta$ & HH. Discount Factor & 0.98 \\
$\delta$ & Depreciation Rate & 0.03 \\
$\eta$ & Dis-utility of Labor & 2.50 \\
$\psi$ & Inv. Labor Supply & 0.80 \\
$t \bar{b} y$ & Trade Balance in Steady State & 0.025 \\
$a$ & Share of Non-Tradables in Consumption & 0.80 \\
$\alpha_{N}$ & Capital Share in Non-Tradable & 0.40 \\
$\alpha_{X}$ & Capital Share in Tradables & 0.60 \\
$\bar{\xi}$ & Prob. of Death of Entrepreneurs in S.S. & $0.05 / 4$ \\
$\psi_{D}$ & Debt Portfolio Adjustment Cost & 0.50 \\
$\rho_{\xi}$ & $A R(1)$ Coefficient of $\xi_{t}$ & 0.90 \\
$\rho_{i^{*}}$ & $A R(1)$ Coefficient of Interest Rate & 0.95 \\
$\sigma_{\xi}$ & SD Entrepreneur Shock & $0.05 / 4$ \\
$\sigma_{i^{*}}$ & SD Interest Rate Shock & 0.025
\end{tabular}

Next, I turn to the estimation of the second subset of parameters: $\left\{\sigma_{e}, \rho_{s}, \kappa \phi, \lambda, \phi_{X}, \phi_{N}\right\}$.These parameters are the persistence of the real exchange rate, the volatility of the real exchange rate, the fraction of firms in the tradable sector that are constraint, the parameter that governs the credit constraint and the degree of substitution across the constrained and unconstrained tradable goods, and the investment adjustment costs for the tradable and non-tradable sectors, respectively. Formally, I estimate these parameters as the solutions to the following minimization problem

$$
J=\min [\widehat{\Psi}-\Psi(\gamma)]_{\gamma}^{\prime} W[\widehat{\Psi}-\Psi(\gamma)]
$$

where $\widehat{\Psi}$ denotes the empirical impulse response function in Figure $6, \gamma$ is the vector of parameters estimated, and $\Psi(\gamma)$ is the model implied IRFs, and $W$ is a diagonal weighting 
matrix. ${ }^{2324}$ Additionally, given that the model is solved using an approximation to its steady state and that the model assumes that the real exchange rate follows an $A R(1)$ process in logarithms, the empirical IRF need to be re-scaled be compared to the model's counterpart.

Note, that in Figure 6 in Section 2 I present three IRFs: the aggregate IRF (without conditioning on the sign of the change of the real exchange rate), the IRF after a depreciation movement of the exchange rate, and the IRF after an appreciation movement of the exchange rate. I carry out two estimation procedures. The main empirical exercise is to use as objective function the matching of the aggregate IRF. A robustness check is to run another exercise in which the estimation procedure tries to match both the aggregate and depreciation IRFs. ${ }^{25}$ The results of both exercises are, unsurprisingly, similar. This similarity arises from several facts: the aggregate IRF from Figure 6 is similar to an average of the appreciation and depreciation IRFs, starting from a steady state a second order perturbation method may not allow the model to capture enough non-linearities in the data. Next section will deal with this last point.

Furthermore, I introduce bounds on the estimation process in order to make the computational procedure more efficient. Table 2 presents the bounds. For the first three parameter, bounds impose no economic restriction. A stable process for the real exchange rate is needed as $\rho_{s} \in$ $(-1,1)$ provides the stability of the economy, and $\kappa$ represents the fraction of constrained firms. Although $\phi<0$ makes no economic sense, I choose $\phi<0.3$ in order to capture that entrepreneurs are in fact credit constrained. Lin et al. (2018) calibrates the value of $\phi=0.2$. Hence, this bound is well above values used in the literature, and the computational advantages are bigger than its potential costs. Lastly, the bounds on $\phi_{X}$ and $\phi_{N}$ represent two extreme cases of investment cost adjustments. If either parameter is equal to zero then there are no adjustments and the IRF will probably lose its hump shape form. While the lower bound makes sense, I choose an upper bound equal to 10, which is 5 times greater than values in the literature (see Garcia Cicco et al. (2012)). The intuition behind this upper bound is that sluggish response of exports can be explained by either tighter financial constraints of higher investment adjustment costs. The upper bound is introduced into the estimation process in order to not overestimate the role of investment adjustment costs beyond values significantly above the ones used in the literature.

\footnotetext{
${ }^{23}$ The choice of the weighting matrix presents a certain degree of arbitrary. The literature has sometimes used the variance of the empirical IRFs along the main diagonal. At the same time, I could potentially choose a weighting matrix that gives specific weighting to the different points in the IRF. For instance, I would like the estimation process to give a higher weight to the initial response a lower to the last observations on the IRF. I take an agnostic view and choose an identity matrix as weight matrix

${ }^{24}$ A preliminary version of the paper had a more sophisticated estimation process where both IRFs and unconditional moments were simultaneously estimated. However, given the focus on the IRFs in Section 2, I present this simpler estimation process.

${ }^{25}$ In order to carry out this second estimation procedure, I weight both IRFs identically.
} 
Table 2. Bounds on Estimated Parameters

\begin{tabular}{c|c}
\hline \hline Parameter & Bounds \\
\hline \hline$\rho_{S}$ & $(-1,1)$ \\
$K$ & {$[0,1]$} \\
$\phi$ & {$[0,0.3]$} \\
$\lambda$ & {$[2,25]$} \\
$\phi_{X}$ & {$[0,10]$} \\
$\phi_{N}$ & {$[0,10]$}
\end{tabular}

Next, I present the results of the IRF matching estimation procedure. Table 3 presents the estimated values of the parameters and Figure 8. In order to match the empirical IRF the model need $77.67 \%$ of the firms in the tradable sector to be credit constrained, and fairly un-persistent exchange rate processes as the auto-regressive coefficient is 0.2219 . At the same time, the degree of substitution between constrained and non-constrained tradable goods is within literature estimates $11.02 .{ }^{26}$ Additionally, the model allows for entrepreneurs to only obtain funding for $28 \%$ the value of the firm, and investment adjustment costs are around 2. From Figure 8 I can observe that the goodness of fit of the model is relatively good overall. The model predicted IRF is lower on impact than the empirical IRF. However, while the empirical sluggishly increases and peaks around 10 quarters after the initial shock, the model responds faster and finds its peak between 4 and 5 quarters after the initial shock. Consequently, the model predicts a much slower decay than the one observed by the empirical measure. This disagreement on the peak and decay of the IRF might be due to features in the data that are not actually present in the model such as additional adjustment costs, shipment and investment lumpiness.

Table 3. Estimated Parameters

\begin{tabular}{c|c|c|c|c|c|c}
\multicolumn{7}{c}{ Parameter } \\
\hline$\sigma_{e}$ & $\kappa$ & $\rho_{s}$ & $\lambda$ & $\phi$ & $\phi_{X}$ & $\phi_{N}$ \\
\hline \hline 0.025 & 0.7767 & 0.2219 & 11.0212 & 0.2799 & 1.9985 & 2.0062
\end{tabular}

${ }^{26}$ For instance, Lin et al. (2018) calibrate the parameter to 11 
Figure 8: Estimated Quantities Exported IRF Result

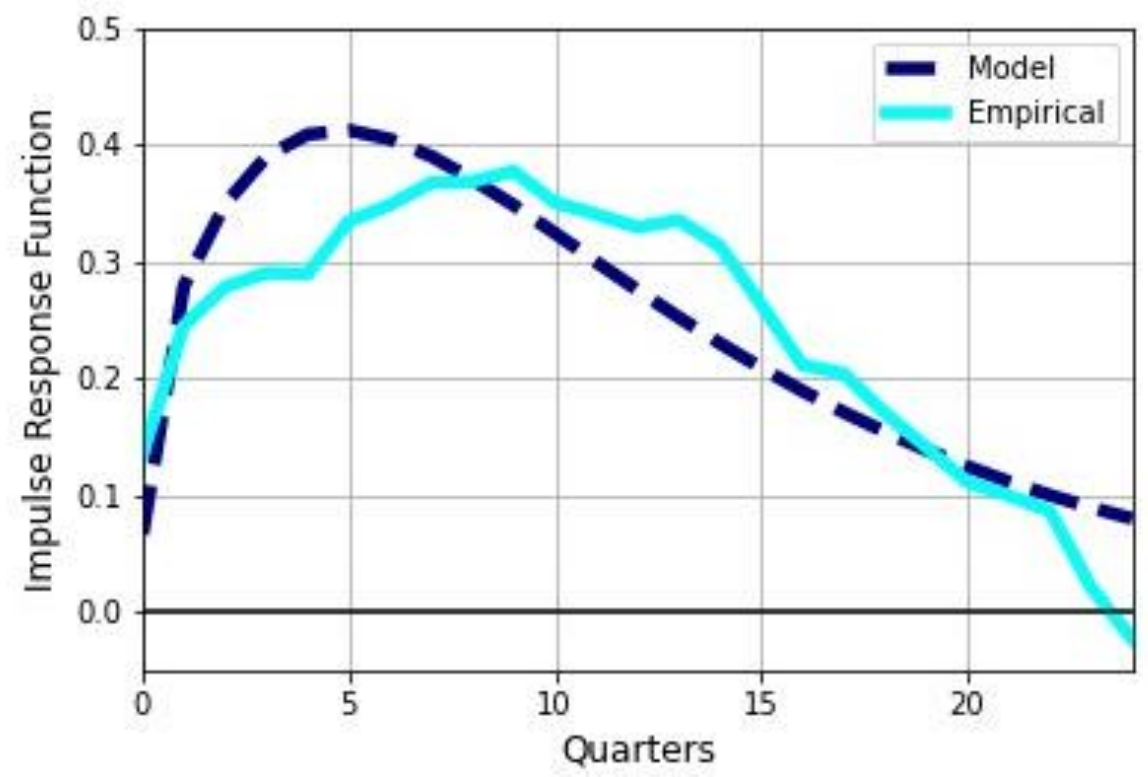

\section{IV.2. Computational Exercises}

In this section of the paper I present a computational exercise to test the ability of the model estimated in the previous section to match the data and stylized facts presented in Section 2. First, I show impulse response functions under different parametrizations, seeking to understand how dynamics of the model depend on the parameters estimated. Next, I will compute Generalized Impulse Response functions for shocks hitting the economy from different points in the economy's ergodic distribution.

First, I start the computational exercises by studying how the impulse response functions of the model change when the fraction of constrained exporters the adjustment costs of capital increase. In particular, I simulate the model using the parameter values presented in Tables 1 and 3 , but change only one parameter. I increase the fraction of constrained exporters from the estimated value of 0.77 to 0.999 . Also, I increase the capital adjustment costs in both sectors around 2 to 10, the upper bounds presented in Table 2. Results from this computational exercise are presented in Figure 9. Increasing the fraction of exporters firms who are constrained reduces the overall response of exports to the shock. Interestingly, with a sufficiently high fraction of exporters constrained, the response on impact is actually negative. On the other hand, increasing the adjustment costs of capital also leads to a muted response of exports. However, this is not enough to lead to a negative impact. 
Figure 9. Robustness Checks on Model IRFs

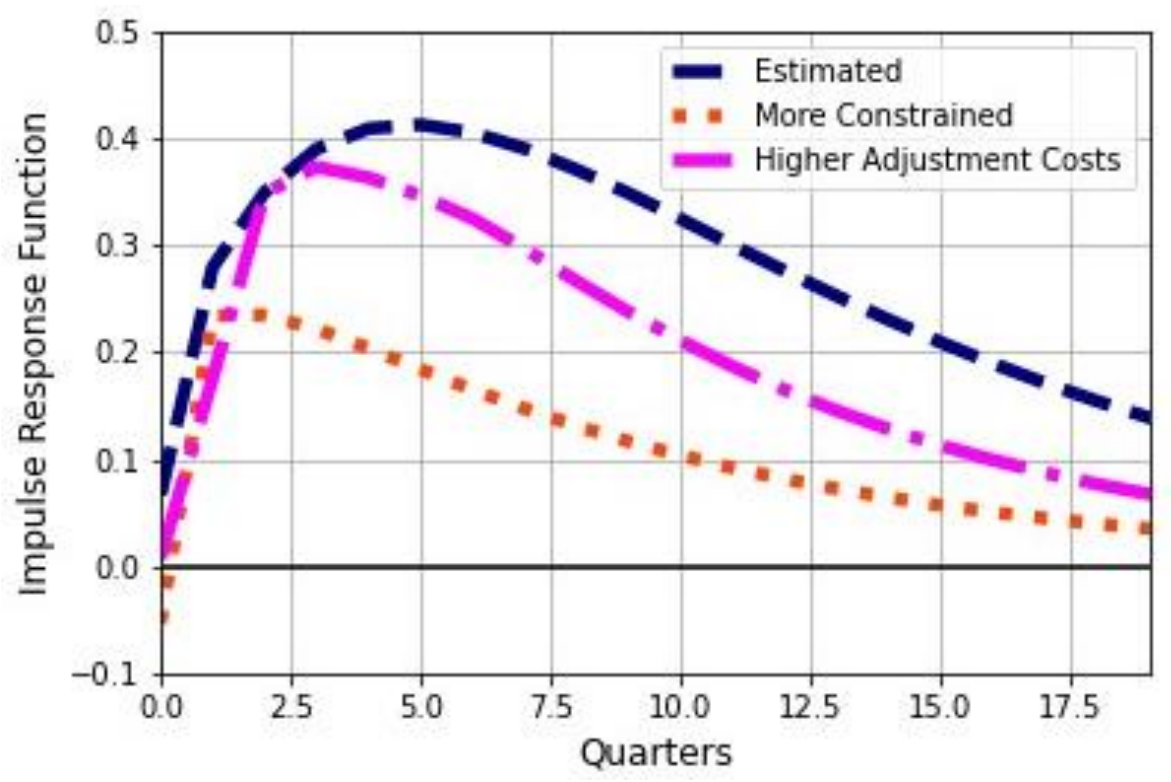

Next, I turn to the study of computational GIRF from different initial points with respect to the steady state. The simulations are carried out using the following procedure. I take the parameters calibrated and estimated in the previous section and simulate the economy for 1200 periods. I drop the first 200 observations as burn-in observations. I take the remaining 1000 observations as representing the ergodic distribution of the model. Next, I hit the economy with a $1 \%$ shock to the real exchange rate and compute the difference between the shocked the economy and the baseline or no shock economy. The plotted IRFs are the average across all the difference. In particular, I will focus on analyzing IRFs assuming that the stock of capital of constrained entrepreneurs start below its steady state value. Hence, I will change the starting point of the $K_{X}^{c}$ from $10 \%$ and $25 \%$ below the steady state. I choose to study the response of exports starting from lower levels of capital because I believe that this initial situation is similar to the economic and financial situation of the episodes presented in Section 2. In other words, situations of low capital, and, consequently, low firm value for entrepreneurs, relate to situations of financial distress.

The results of the computational exercise are presented in Figure $10 .{ }^{27}$ Note that the following exercise comprises of comparing dynamics starting from different values of the stock of capital of entrepreneurs. The results are somewhat puzzling. On impact, all impulse response functions are remarkably similar. This similar and rapid increase in exports is might be explained by the fact that stocks of capital are fixed on impact. However, the differences in initial stocks of capital are reflected on the dynamics of exports shortly after impact. While the dynamics starting from entrepreneur capital $10 \%$ lower than the steady state value leads only to a slightly lower export expansion, starting from an entrepreneur capital $25 \%$ lower than steady state leads to significantly

${ }^{27}$ Note that this GIRFs are not directly comparable with the IRFs presented in section above. The IRFs computed to estimate the model are different as they are perturbations starting from a situation in which the whole economy is on its deterministic steady state. 
non-linear dynamics. After the initial increase in exports, the IRF is significantly reduced, remaining below the other two IRFs for the rest of the time horizon.

Figure 10: GIRF of Quantities Exported with Low Entrepreneur Capital

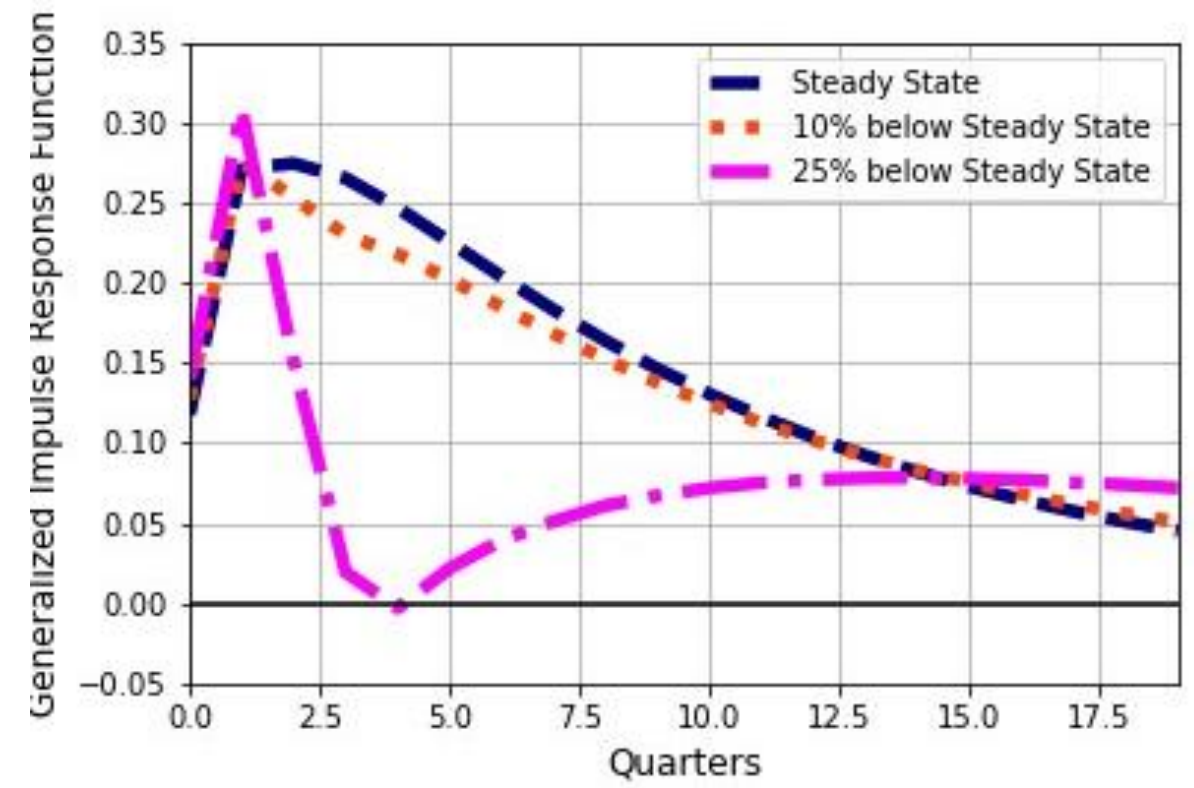

In conclusion, the model presented in this Section of the paper introduced entrepreneurs facing with credit constraints into a small open two-sector economy. The IRF matching estimation procedure yield somewhat satisfying results. While the model seems to be able to match the aggregate IRF presented in Section 2, the model does not seem to be able to generate non-linear dynamics similar to those in Figure 6.

\section{Conclusions}

The present paper studied the dynamics of international trade at the aggregate and firm level during episodes of severe financial stress. and later presented a medium scale small open economy DSGE with credit constraints to try and replicate the empirical findings.

The starting point of the investigation is the notion that trade balance improvements associated to financial crises is explained primarily by a collapse in imports and not an increase in exports. I present evidence showing that exports react sluggishly during episodes of financial crises. I use firm level data for two countries and to episodes of financial crises, Argentina 2001 and Peru 1998. I show that the number of exporting of firms does not increase significantly after the crisis (even more, it falls during the crisis) and that the poor export performance is primarily explained by the intensive margin or incumbent exporters, not the entry and exit of firms from foreign markets. Furthermore, I present firm level data evidence that the both on impact and dynamically, quantities exported react faster and stronger to appreciation movements of the real exchange rate than to depreciation movements of the real exchange rate. 
I introduce credit constraints into a small open economy model in which real depreciations lead to tighter financial constraints in order to try to match the empirical findings. I calibrate and estimate parameters of the model using the estimated IRFs. While the model is able to match an empirical IRF, it does not yield non-linearities similar to those present in the data.

Going forward, I believe it is necessary to introduce additional frictions into the model. In particular, frictions highlighted by the literature on international trade, such as customer capital accumulation, lumpy shipments and or lumpy behavior, and learning over foreign demand. Also, additional frictions on the market for production factors, such as search and matching frictions on the labor market would help the model better fit non-linearities. Finally, given that only a small subset of firms actually engage in exporting ${ }^{28}$, introducing firm heterogeneity should be on the research agenda.

\section{References}

Albornoz F., Calvo Pardo H. F., Corcos G., and Ornelas E. (2012). Sequential exporting. Journal of International Economics, 88(1), 17-31.

Albuquerque R., Eichenbaum M., Luo V. X., and Rebelo S. (2016). Valuation risk and asset pricing. The Journal of Finance, 71(6), 2861-2904.

Alessandria G., Pratap S., and Yue V. Z. (2013). Export dynamics in large devaluations. Working Paper.

Berman N., Martin P., and Mayer T. (2012). How do different exporters react to exchange rate changes?. The Quarterly Journal of Economics, 127(1), 437-492.

Cavallo E., Powell A., Pedemonte M., and Tavella P. (2015). A new taxonomy of sudden stops: Which sudden stops should countries be most concerned about? Journal of International Money and Finance, 5, 47-70.

Chatterjee A., Dix-Carneiro R., and Vichyanond J. (2013). Multi-product firms and exchange rate fluctuations. American Economic Journal: Economic Policy, 5(2),77-110.

Coremberg A. A. (2007). La medición de la productividad y los factores productivos. $\mathrm{PhD}$ thesis, Universidad Nacional de La Plata.

Coremberg A. A. (2009). Midiendo las fuentes del crecimiento en una economía inestable: Argentina. Productividad y factores productivos por sector de actividad económica y por tipo de activo. CEPAL.

Eaton J., Eslava M., Kugler M., and Tybout J. (2008). The margins of entry into export markets: evidence from Colombia.

\footnotetext{
${ }^{28}$ See Melitz (2003) and Albornoz et al. (2012) for Argentina
} 
Fernandes A. M., Freund C., and Pierola M. D. (2016). Exporter behavior, country size and stage of development: Evidence from the exporter dynamics database. Journal of Development Economics, 119(1), 121-137.

Garcia Cicco, J., Heresi, R., and Naudon, A. (2012). The real effects of global risk shocks in small open economies. mimeograph, LACEA.

Garcia-Cicco J., Pancrazi R., and Uribe M. (2010). Real business cycles in emerging countries? American Economic Review, 100(5), 2510-31.

Gopinath G. and Neiman B. (2014). Trade adjustment and productivity in large crises. American Economic Review, 104(3), 793-831.

Jordà O. (2005). Estimation and inference of impulse responses by local projections. American economic review, 95(1), 161-182.

Kiyotaki N. and Moore J. (1997). Credit cycles. Journal of political economy, 105(2), 211-248.

Kohn D., Leibovici F., and Szkup M. (2016). Financial frictions and new exporter dynamics. International economic review, 57(2), 453-486.

Kohn, D., Leibovici, F., and Szkup, M. (2020). Financial frictions and export dynamics in large devaluations. Journal of International Economics, 122: 103257.

Lin, S., Shi, K., and Ye, H. (2018). Exchange rate volatility and trade: The role of credit constraints. Review of Economic Dynamics, 30, 203-222.

Melitz M. J. (2003). The impact of trade on intra-industry reallocations and aggregate industry productivity. econometrica, 71(6), 1695-1725.

Schmitt-Grohé S. and Uribe M. (2003). Closing small open economy models. Journal of international Economics, 61, 163-185.

Uribe M. (2018). The neo-fisher effect: Econometric evidence from empirical and optimizing models. Technical report, National Bureau of Economic Research. 


\section{Appendix A. Macroeconomic Model Characterization}

In this Appendix I present the equilibrium conditions of the Macroeconomic Model presented in Section 5.

\section{A.1. Household: 5 equations}

$$
\begin{gathered}
\mathbb{E}_{t}\left\{\frac{1-\psi_{D}\left(d_{t}-\bar{d}\right)}{1+i_{t+1}^{*}}\right\}=\beta \mathbb{E}_{t}\left\{\frac{c_{t}}{c_{t+1}}\right\} \\
\beta\left(1-\delta+\mathbb{E}_{t}\left\{r_{t+1}\right\}\right)=\mathbb{E}_{t}\left\{\frac{c_{t+1}}{c_{t}}\right\} \\
w_{t}=\eta l_{t}^{\psi} c_{t} \\
k_{t}^{x u}=\mathbb{E}_{t}\left\{\frac{\alpha^{x} p_{t+1}^{x u} y_{t+1}^{x u}}{\alpha^{x} p_{t+1}^{x u} y_{t+1}^{x u}+\alpha^{n} p_{t}^{n} y_{t}^{n}}\right\} k_{t} \\
k_{t}=k_{t}^{x u}+k_{t}^{n}
\end{gathered}
$$

\section{A.2. Production}

\section{A.3. Non-Traded Sector: 5 equations}

$$
\begin{gathered}
p_{t}^{n}=r_{t}^{\alpha^{n}} w_{t}^{1-\alpha^{n}} \\
y_{t}^{n}=\frac{\alpha z_{t}}{p_{t}^{n}} \\
r_{t}=\frac{\alpha^{n} p_{t}^{n} y_{t}^{n}}{k_{t-1}^{n}} \\
l_{t}^{n}=\frac{\left(1-\alpha^{n}\right) y_{t}^{n} p_{t}^{n}}{w_{t}} \\
i_{t}^{n}=k_{t}^{n}-(1-\delta) k_{t-1}^{n}
\end{gathered}
$$




\section{A.4. Unconstrained Traded Sector: 4 equations}

$$
\begin{gathered}
p_{t}^{x u}=r_{t}^{\alpha^{x}} w_{t}^{1-\alpha^{x}} \\
y_{t}^{x u}=(1-\kappa)\left(\frac{p_{t}^{x u}}{p^{x *}}\right)^{-\lambda} y_{t}^{x} \\
l_{t}^{x u}=\left(1-\alpha^{x}\right) \frac{w_{t}}{p_{t}^{x u}} y_{t}^{x u} \\
i_{t}^{x u}=k_{t}^{x u}-(1-\delta) k_{t-1}^{x u}
\end{gathered}
$$

\section{A.5. Constrained Traded Sector: 9 equations}

$$
\begin{aligned}
& p_{t}^{x c}=\left(r_{t}^{x c}\right)^{\alpha^{x}} w_{t}^{1-\alpha^{x}} \\
& y_{t}^{x c}=\kappa\left(\frac{p_{t}^{x c}}{p_{t}^{x *}}\right)^{-\lambda} y_{t}^{x} \\
& \mathbb{E}_{t}\left\{\frac{\beta(1-\epsilon)\left(r_{t+1}^{x c}+1-\delta\right)}{c_{t+1}^{e}}\right\}=\frac{1}{c_{t}^{e}}-\phi \bar{\lambda}_{t} K_{t} \\
& b_{t}=\phi \mathbb{E}_{t}\left\{V F_{t+1}\right\} \\
& V_{t}^{f}=p_{t}^{x c} y_{t}^{x c}-w_{t} l_{t}^{x c}+b_{t}-\left(1+r_{t}-\delta\right) b_{t-1}-i_{t}^{x c}+\beta(1 \\
& -\epsilon) \mathbb{E}_{t}\left\{V F_{t+1}\right\} \\
& K_{t}=\mathbb{E}_{t}\left\{\frac{r_{t}^{x c}+1-\delta}{1+\phi\left(1+r_{t+1}-\delta\right)}\right\} \\
& \bar{\lambda}_{t}=\frac{1}{c_{t}^{e}}-\beta(1-\epsilon) \mathbb{E}_{t}\left\{\frac{1+r_{t+1}-\delta}{c_{t+1}^{e}}\right\} \\
& r_{t}^{x c}=\frac{\alpha^{x} p_{t}^{x c} y_{t}^{x c}}{k_{t-1}^{x c}} \\
& l_{t}^{x c}=\frac{\left(1-\alpha^{x}\right) y_{t}^{x c} p_{t}^{x c}}{w_{t}}
\end{aligned}
$$




$$
\begin{gathered}
i_{t}^{x c}=k_{t}^{x c}-(1-\delta) k_{t-1}^{x c} \\
c_{t}^{e}=p_{t}^{x c} y_{t}^{x c}-w_{t} l_{t}^{x c}+b_{t}-\left(1+r_{t}-\delta\right) b_{t-1}-i_{t}^{x c}
\end{gathered}
$$

A.6. Composite Price and Other: 3 equations

$$
\begin{gathered}
p_{t}^{x *}=\left[\kappa\left(p_{t}^{x c}\right)^{1-\lambda}+(1-\kappa)\left(p_{t}^{x u}\right)^{1-\lambda}\right]^{\frac{1}{1-\lambda}} \\
s_{t}=\frac{p_{t}^{x *}}{p_{t}^{f *}} \\
1=\left(p_{t}^{n}\right)
\end{gathered}
$$




\section{Appendix B. Description for the Aggregate Level Analysis}

First, I describe the data sets used to perform our aggregate level analysis. Given that several of the countries in our sample are developing economics and lack high frequency macroeconomic data a starting point is the Penn World Tables v9.1 data. I construct export and import series using the shares of exports and imports and multiplying them by GDP at constant prices.

Next, I present the 18 episodes of rapid current account reversals I will study in detail in this paper. First, I take the cases studied by Alessandria et al. (2013) in which current account reversals in emerging markets are accompanied by large currency devaluations: Argentina 2001, Brazil 1998, Indonesia 1998, Korea 1997, Malaysia 1997, Mexico 1994, Russia 1998, Thailand 1997, Turkey 2001, Uruguay 2002. Next, I study the performance of developed countries in the Euro Zone in the last financial crisis (Portugal, Ireland, Greece and Spain) which share a currency union. Third, I study the case of Ecuador in 1998 which is a country who has formally accepted the dollar as its currency. Fourth, I study the financial crisis in Finland and Sweden in the early 1990s where developed countries faced both a banking and a currency crisis. Finally, I study Brazil's 2014 recession, the country's largest GDP drop in recorded history.

In terms of the methodology used, for most of the empirical exercises in this paper I think of these episodes as case studies. Thus, I define $t=0$ as the last period of macroeconomic expansion before the rapid trade balance adjustment. ${ }^{29}$ Furthermore, I will normalize the value of the variables at $t=0$ in order to ease comparison. These normalizations help study the dynamics at different time horizons, both before and after the events. The specific times horizons used will depend on the frequency of the data used and on data availability.

\footnotetext{
${ }^{29}$ In other words, period " $t+1$ " represents one period after the trade balance adjustment.
} 